\title{
MENILIK PERTUNJUKAN ADU DOMBA di pRiangan pada masa kolonial
}

\author{
THE FIGHTING SHEEP SHOW IN PRIANGAN \\ DURING THE COLONIAL PERIOD
}

\author{
Budi Gustaman \\ Departemen Sejarah dan Filologi, Fakultas Ilmu Budaya, Universitas Padjadjaran \\ Jl. Raya Bandung - Sumedang Km. 21, Jatinangor \\ e-mail: budi.gustaman@unpad.ac.id
}

Naskah Diterima: 1 Mei $2021 \quad$ Naskah Direvisi: 31 Agustus $2021 \quad$ Naskah Disetujui : 18 Oktober 2021

DOI: $10.30959 /$ patanjala.v13i2.788

\begin{abstract}
Abstrak
Adu domba sangat populer di Priangan, khususnya di wilayah Garut. Popularitas adu domba (Garut) tidak bisa dilepaskan dari historisitasnya. Penelitian ini ditujukan untuk mempertanyakan kemunculan domba Garut serta pertunjukan adu domba pada awal perkembangannya. Metode yang digunakan adalah metode sejarah, dengan memanfaatkan sumber berupa buku dan koran yang diproduksi pada masa kolonial. Temuan utama penelitian ini ialah kemunculan jenis domba Garut dilatarbelakangi impor domba yang diinisiasi oleh K.F. Holle untuk tujuan budidaya wol. Kawin silang domba impor dan domba lokal menghasilkan jenis domba petarung yang lazim disebut domba Garut. Pertunjukan adu domba muncul dari kebiasaan masyarakat pribumi dalam mengadu binatang, hingga berkembang menjadi hiburan yang sering diselenggarakan pada setiap event besar. Kesimpulan penelitian ini adalah sebagai domba petarung, domba Garut muncul dari 'ketidaksengajaan' hingga menjadi populer sejak akhir abad ke-19, dengan diiringi berbagai kecaman dari perspektif orang Eropa perihal esensi permainannya.
\end{abstract}

Kata kunci: Adu Domba, Domba Garut, Garut, Priangan.

\begin{abstract}
Fighting sheep is very popular in Priangan, especially in the Garut region. The popularity of fighting sheep can't be separated from the history that lies behind it. This research is intended to answer the questions about the emergence of Garut sheep and sheep fighting show at the beginning of its development. The method used in this research is the historical method by utilizing sources of books and newspapers produced during the colonial period. The main finding of this study is that the emergence of the Garut sheep breed was motivated by the import of sheep initiated by K.F. Holle for wool cultivation purposes. The crossbreeding of imported sheep and local sheep has resulted in the type of fighting sheep which is now commonly referred to as Garut sheep. The fighting sheep show itself emerged from the indigenous people's habit of fighting animals which later developed into an entertainment that was often held at every major event. The conclusion of this study is that Garut sheep as fighting sheep emerged from an 'accidental habits' and then became popular since the late $19^{\text {th }}$ century. On the other hand, it has also drawn criticism from the perspective of Europeans who are concerned about the essence of the fighting sheep.
\end{abstract}

Keywords: fighting sheep, Garut sheep, Garut, Priangan. 


\section{A. PENDAhuluan}

Dilansir dari situs resmi Dinas Pariwisata dan Budaya Provinsi Jawa Barat, seni ketangkasan adu domba termasuk salah satu atraksi wisata unggulan di Jawa Barat, khususnya di Kabupaten Garut. Domba Garut pada dasarnya memiliki nilai yang tinggi sebagai sebuah komoditas budaya maupun komoditas ekonomi, termasuk sebagai aset untuk meningkatkan sektor pariwisata. Terlebih, popularitas domba Garut terus menanjak, hingga pernah masuk ke lingkungan Istana pada 27 Agustus 2016 lalu. Beberapa di antaranya berjalan di atas karpet merah disambut langsung oleh Presiden. Dalam kontes domba yang bertajuk Piala Kemerdekaan Republik Indonesia tersebut, Presiden memberi pesan bahwa domba Garut merupakan simbol seni, budaya, dan kebangkitan ekonomi kerakyatan.

Popularitas domba Garut pada dasarnya tidak bisa dilepaskan dari sejarahnya yang identik sebagai binatang petarung. Masyarakat Sunda memiliki minat yang besar terhadap pagelaran adu domba. Adu domba kerap digelar pada setiap kemeriahan yang diselenggarakan di Tatar Sunda. Kondisi ini sejatinya telah terlihat sejak masa kolonial, yaitu ketika domba Garut dan pertarungannya, sudah sangat populer di kalangan masyarakat Priangan sejak masa kolonial.

Narasi tentang sejarah domba Garut dan pagelaran adunya sebenarnya banyak diulas pada portal-portal daring. Namun, terkadang ada beberapa fakta yang berbeda dalam penyampaiannya, termasuk sumbersumber yang dirujuknya, sehingga perlu dipertegas dengan data-data yang bisa dipertanggungjawabkan secara faktual. Untuk itu, tulisan ini diikhtiarkan untuk menarasikan kembali eksistensi domba Garut di masa-masa awal perkembangannya. Adapun tiga pertanyaan utama yang perlu dijawab adalah: Pertama, bagaimana narasi historis perihal kemunculan jenis domba Garut? Kedua, bagaimana pagelaran adu domba Garut pada masa kolonial, serta bagaimana pemaknaannya di mata orang-orang Eropa dan pemerintah kolonial?

Penelusuran diawali dengan pembacaan sumber-sumber yang diproduksi pada awal abad ke-19, baik koran, buku, ataupun catatan perjalanan. Sumber-sumber pada awal abad ke-19 ternyata tidak ada yang menarasikan penyelenggaraan adu domba di Priangan, meski pertunjukan mengadu binatang merupakan hal yang lazim dilakukan di Jawa sebelum abad ke-19. Setidaknya, Thomas Stamford Raffles mengemukakan hal ini dalam The History of Java. Raffles (1830: 386-390) mengemukakan bahwa ada beberapa pertarungan binatang yang kerap dijadikan tontonan di Jawa, yakni adu harimau dengan kerbau (rampogan), adu banteng, adu biri-biri jantan dengan babi liar, adu burung puyuh, adu ayam, serta adu jangkrik.

Kolega Raffles, John Crawfurd (1820: 113-117) juga mencatat beberapa adu binatang dalam buku berjudul History of the Indian Archipelago. Adu ayam, adu burung puyuh, adu jangkrik, adu harimau dengan banteng, adu banteng, serta adu babi liar dengan kambing dan domba adalah pertarungan binatang yang lazim dilakukan di Nusantara. Permainan adu domba telah ada meski bertarung dengan babi liar, di mana Crawfurd menyebutnya sebagai "suatu pertarungan yang menggelikan tanpa darah".

Pada 1860-an, tulisan Karel

Frederick Holle dalam Tijdschrift voor Nijverheid en Landbouw in NederlandschIndie memberi landasan awal perihal budidaya domba di Priangan. Tulisan tersebut mengantarkan pada hipotesis bahwa tahun 1860-an menjadi masa awal budidaya domba Garut di Priangan, khususnya domba jenis petarung. Pembacaan terhadap tulisan tersebut juga menghadirkan hipotesis lain bahwa hadirnya domba petarung berawal dari kegagalan dalam pembudidayaan wol. Adu domba (Garut) selanjutnya banyak disebutkan pada beberapa koran yang diproduksi pada akhir abad ke-19, seiring 
dengan masifnya budidaya domba di Priangan. Perlahan, adu domba menjadi kebiasaan yang sering dilakukan anak-anak penggembala, hingga menjadi suatu tontonan yang kerap menghiasi berbagai acara berskala besar di wilayah Priangan. Popularitas adu domba nyatanya menyisakan kritik dari orang-orang Eropa perihal esensi kekerasan yang ada dalam penyelenggaraannya. Adu domba pun menjadi suatu permasalahan yang memperlihatkan ambiguitas antara hiburan dan kekejaman terhadap binatang.

Secara umum, popularitas adu domba yang dirasakan sekarang muncul dari dimensi sosio-kultural masyarakat Sunda masa kolonial. Tentu, dengan tidak mengabaikan eksistensi orang Eropa dalam menghadirkan dan menarasikan pertunjukan popular tersebut, terlepas dari berbagai pandangan normatif terhadapnya.

\section{B. METODE PENELITIAN}

Penelitian ini menggunakan metode sejarah yang terdiri atas heuristik, kritik, interpretasi, dan historiografi. Disebabkan kondisi pandemi Covid-19, heuristik atau pencarian sumber sejarah dilakukan secara daring melalui laman web delpher.nl, archive.org, dan digital collection Leiden University. Laman web delpher.nl menyediakan sumber-sumber digital yang menarasikan adu domba di Priangan, berupa buku, koran, dan majalah, baik terbitan Hindia Belanda maupun terbitan Belanda. Koran atau majalah yang digunakan dalam penelitian ini di antaranya De Preanger-Bode, De Locomotief, dan Bataviaasch Nieuwsblad. Sementara itu, beberapa koran pribumi, seperti Kaoem Moeda dan Matahari, yang terhimpun dalam Overzicht van de Inlandsche en Maleisch-Chineesche Pers, juga menjadi rujukan penting. Selain itu, sumber penting lain yang digunakan adalah tulisan K.F. Holle berjudul "Merinos-Schapen", yang terhimpun dalam Tijdschrift voor Nijverheid en Landbouw in Nederlandsch Indie.
Pada tahap kritik dilakukan pengujian dan pembandingan beberapa sumber untuk menguji otentisitas dan kredibilitasnya. Misalnya, ada tendensi untuk melihat awal mula budidaya domba Garut di Priangan. Tulisan K.F. Holle dalam Tijdschrift voor Nijverheid en Landbouw in Nederlandsch Indie - yang berisi data perihal proses kawin silang domba impor dengan domba lokal - adalah sumber "tertua" yang membahas hal tersebut. Sumber ini diperkuat dengan sumber lain, seperti sumber M. Buys berjudul In het Hart der Preanger yang ditulis pada 1900. Selain itu, penting juga untuk "membuktikan" narasi yang menyebutkan Bupati Suryakantalegawa yang menginisiasi lahirnya jenis domba Garut, seperti yang disebutkan pada portalportal online. Jika mengacu pada sumber yang memuat periodisasi pemerintahan di Priangan, maka pada masa R. Adipati Wiratanu Datar VII (1836-1871) lah awal mula domba Garut dibudidayakan. Periode tersebut sejalan dengan informasi yang diungkapkan K.F. Holle yang melakukan proses kawin silang domba impor dan domba lokal pada 1860-an. Hal ini tentunya keliru jika mengacu pada masa pemerintahan Bupati Suryakantalegawa yang menjabat pada 1915 hingga 1929. Namun demikian, tidak menutup kemungkinan jika Bupati Suryakantalegawa memiliki minat yang besar pada budidaya domba Garut. Hal tersebut memerlukan penelitian lebih lanjut.

Pada tahap interpretasi dilakukan beberapa penafsiran terhadap fakta-fakta yang ada. Misalnya, dongeng Roesdi djeung Misnem karangan A.C. Deenik dan Raden Djajadiredja merepresentasikan (sejauh mana) pemaknaan adu domba dalam masyarakat Sunda. Dongeng yang bercerita menyoal keseharian masyarakat Sunda tersebut, menyisipkan cerita tentang kebiasaan menggembala domba dalam keseharian anak-anak Sunda. Selain itu, dikisahkan pula mengenai hajatan seorang camat yang menggelar adu domba sebagai 
salah satu kemeriahan di wilayahnya. Singkatnya, dongeng yang dibuat pada awal abad ke-20 tersebut merepresentasikan kondisi masyarakat pada zamannya. Tahap historiografi atau penulisan pada akhirnya menjadi bagian akhir metode sejarah, di mana dilakukan penulisan fakta-fakta yang disusun secara sistematis.

\section{HASIL DAN BAHASAN}

\section{Asal Usul Domba Garut}

Dalam beberapa literatur yang diproduksi sejak pertengahan abad ke-19, penyebutan 'domba Priangan' lebih lazim digunakan dibandingkan penyebutan 'domba Garut' pada masa sekarang. Domba Priangan merupakan jenis domba hasil persilangan antara domba Kaapse atau Cape, domba Jawa (jenis domba lokal), dan domba Merino. Pada abad ke-20, Garut menjadi pusat penangkaran domba di Jawa (Barwegen, 2005: 65). Hal ini lah yang membuat domba begitu identik dengan Garut.

Sebelum dikenal domba berjenis campuran, di wilayah Priangan telah ada jenis domba lokal yang oleh orang Belanda dikenal sebagai "domba Jawa" atau "domba Hindia". Orang-orang Belanda memiliki cara pandang khusus terkait keberadaan domba di Priangan, yakni nilai komersil yang bisa diambil dari pemanfaatan bulu domba untuk pemintalan wol, seperti yang dilakukan di Eropa. Namun, bulu domba lokal dianggap terlalu lurus dan berantakan. Bahkan, sampel bulu domba lokal yang dikirim ke Inggris disebut sebagai "stok paling kasar yang pernah dilihat". Impor domba Merino dilakukan untuk mendapatkan bulu domba berkualitas baik, tetapi upaya ini dianggap tidak memuaskan (Veeteelt overdruk uit Mededeelingen der Regering Omtrent, 1926: 131).

K.F. Holle berperan besar atas impor domba Merino pada medio abad ke-19. Hasil persilangan antara domba lokal dengan domba impor menghasilkan jenis domba Garut atau domba Priangan yang memiliki ciri tubuh lebih kurus dan berbulu sedikit jika dibandingkan dengan domba di Eropa. Sementara itu, domba jantan umumnya memiliki tubuh yang kokoh dan kaki yang kuat, berukuran besar, berekor panjang, serta dihiasi tanduk yang melengkung indah (Buys, 1900: 132133).

Dalam tulisannya di Tijdschrift voor Nijverheid en Landbouw in NederlandschIndie, K.F. Holle menyebutkan bahwa sebelum Juni 1866 ia mengimpor sebanyak 37 ekor domba, dengan rincian: 1 domba jantan, 15 domba betina, 10 anak domba betina, dan 11 anak domba jantan. K.F. Holle lebih rinci lagi menyebutkan bahwa dari keseluruhan domba yang diimpor, ada beberapa domba yang mati, yakni 2 domba betina, 1 anak domba betina, dan 1 anak domba jantan. Dua domba betina yang mati kemungkinan disebabkan usianya yang sudah tua. Salah satu domba terlihat tampak sehat sebelum mati mendadak. Sementara itu, kedua anak domba yang mati adalah anak domba tidak berinduk, yang sulit untuk beradaptasi dengan domba betina yang bukan induknya (Holle, 1868:162-165).

Selanjutnya, beberapa anak domba impor tersebut diberikan kepada para pembesar di Priangan, seperti Bupati Limbangan (1 anak domba jantan dan 1 anak domba betina), Tuan van Nispen di Sumedang (1 anak domba jantan), Tuan Levyssohn di Sumedang (1 anak domba jantan), Tuan Loheijde di Bandung (1 anak domba jantan), Hoofdpanghoeloe (Kepala Penghulu) di Garut (1 anak domba jantan dan 1 anak domba betina), serta Hoofdgekommitteerde voor koffij-kultuur (Komisaris Utama Perkebunan Kopi) di Garut (1 anak domba jantan) (Holle, 1868:163).

"De ram, dien ik aan den regent afstond, is reeds flink opgeschoten en belooft wat zijn uiterlijk betreft niet voor zijn vader te zullen onderdoen. Ik heb zelfs reden om te vooronderstellen, dat wij hier 
spedig in de gelegenheid zullen zij te beoordeelen in hoeverre zijne nakomelingen naar hem aarden".

"Domba yang saya berikan kepada bupati [Limbangan $]^{1}$ sudah mengalami kemajuan yang baik dan tidak akan kalah dengan penampilan ayahnya [domba Merino jantan]. Saya bahkan punya alasan untuk mengira bahwa akan segera dapat menilai sejauh mana keturunannya bahwa di sini kita akan segera bisa menilai sejauh mana keturunannya memiliki kesamaan karakter dengannya..." (Holle, 1868: 163).

Budidaya pemintalan wol memang menjadi saah satu tujuan K.F. Holle dalam upaya mengawinsilangkan domba impor dengan domba lokal. Dalam hal ini, dilakukan pula perkawinan silang dengan "Kaapsche schapen" (domba Cape),

\footnotetext{
${ }^{1}$ Jika mengacu pada tahun ditulisnya sumber ini oleh K.F. Holle, maka bupati yang dimaksudkan adalah R. Adipati Wiratanu Datar VII yang menjabat bupati Limbangan (Garut) pada periode 1836-1871. Hal yang menjadi suatu kesulitan adalah "membuktikan" asal usul domba Garut, yang banyak disebutkan oleh berbagai media online (termasuk situs resmi Dinas Pariwisata dan Budaya Provinsi Jawa Barat), bahwa kemunculan domba Garut diinisiasi oleh Bupati Garut Suryakantalegawa yang menjabat pada periode 1915-1929 (bahkan dalam situs resmi Dinas Pariwisata dan Budaya Provinsi Jawa Barat terdapat kesalahan dalam penulisan periode pemerintahan Bupati Suryakantalegawa, yakni 1815-1829). Hal ini perlu dilakukan penelitian lebih lanjut. Adapun bupati Limbangan (Garut) yang menjabat pada medio abad ke-19 hingga medio abad ke-20 ialah: R. Adipati Wiratanu Datar VII (1836-1871), R. Adipati Wiratanu Datar VIII (1871-1915), R.A.A Suryakantalegawa (1915-1929), dan R.A.A. Muhamad Musa Suryakantalegawa (19291944) (Lubis, 1998: 320).
}

seperti yang dilakukan oleh K.F. Holle yang mengawinkan dombanya dengan domba Kaapse milik Bupati Limbangan. “... het Kaapsche schaap meestaal meer dan 1 jong werpt en dus spediger vermenigvuldigt dan het merino-schaap, dat, hier althans, slechts een jong ter wereld brengt ... het Kaapsche schaap grooter van gestalte".

“... domba Kaapse biasanya melahirkan lebih dari satu anak dan berkembang biak lebih cepat daripada domba Merino, yang setidaknya di sini melahirkan satu anak ... domba Kaapse bertubuh lebih besar" (Holle, 1868: 165).

Namun demikian, K.F. Holle menilai bahwa perkembangbiakan domba kurang begitu diminati penduduk pada pertengahan abad ke19 (Holle, 1868: 164-165).

Salah satu faktor penyebab kurangnya minat penduduk Priangan pada budidaya domba ialah kebutuhan penduduk Priangan yang relatif kecil pada daging, yang cukup terpenuhi oleh budidaya kerbau. Begitupun minat yang kurang dalam pemanfaatan bulu domba untuk pemintalan wol (Buys, 1900: 133). “... zij op de wol der schapen geen prijs stellen, gelijk blijkt uit het feit, dat zij deze eenvoudig wegwerpen als de schapen geschoren zijn. Deze verkwisting is te meer te betreuren in een koel en voctig berland, waar enkele wollen artikelen, zoaal dekens en baadjes, ook bij de inlanders die ze betalen kunnen - zeer gewild zijn. Kon men hen bewegen om de wol te gaan spennen en weven ... dan zou hun hiermede eene nieuwe, hoezeer dan ook bescheiden, 
bron van inkomsten geopend worden."

“... Mereka tidak menghargai bulu domba, sebagaimana fakta bahwa mereka begitu saja membuangnya ketika domba dicukur. Limbah ini lebih disesalkan di negara pegunungan yang sejuk dan lembab, di mana beberapa barang wol seperti selimut dan baju sangat diminati penduduk yang mampu membelinya. Jika mereka dapat dibujuk untuk meminta dan menenun wol ... itu akan membuka sumber pendapatan baru bagi mereka." (Buys, 1900: 133).

Secara umum, peternakan domba di Hindia Belanda menempati posisi yang tidak begitu strategis. Upaya untuk mengembangkan produksi wol dengan mengembangkan peternakan domba merino juga kurang memuaskan, sehingga lambat laun peternakan domba yang berorientasi pada produksi wol mulai ditinggalkan (Stroomberg, 2018: 247).

Meski tidak menghasilkan kepuasan dalam budidaya wol, nyatanya pembiakan yang intensif antara domba lokal dengan domba impor menghasilkan jenis domba Garut yang bernilai tinggi, terutama jenis domba adu yang banyak dipelihara di wilayah barat Priangan. Pada 1926, domba adu ini harganya bisa mencapai f $100-\mathrm{f}$ 150 (Buys, 1900: 133).

\section{Pagelaran Adu Domba}

"Karasmenan keur pesta ti beurang, di alun-alun geus diatur: tangkal jambe beunang ngabalur ku gajih, diluhurna digantungan rupa-rupa kahakanan. Jajangkungan, maen colok, ngadu domba, maen calung, jeung tatabeuhan geus ngajajar ... Sora hulu domba nu diadu tinggeleduk matak rieut $\mathrm{nu}$ alajo. $\mathrm{Nu}$ bogana
dombana."

"Keramaian dalam pesta dari siang sudah diatur di alun-alun: pohon jambe [pinang] sudah diolesi oleh lemak, di atasnya digantung berbagai makanan. [permainan] Jajangkungan, main colok, adu domba, main calung dan perangkat musik sudah berjajar ... Suara kepala domba yang beradu membuat pusing bagi yang menonton. Pemiliknya memberi dukungan pada dombanya (Deenik dan Djajadiredja, 1913: 66-67).

Penggalan dongeng berjudul Roesdi djeung Misnem di atas menggambarkan kemeriahan pesta di suatu alun-alun yang menampilkan banyak pertunjukan, salah satunya ngadu domba, sebagai bentuk sebuah pesta hajat yang diselenggarakan oleh seorang Camat. Dongeng tersebut merepresentasikan kebiasaan masyarakat Sunda yang kerap menjadikan adu domba sebagai suatu hiburan besar yang diselenggarakan untuk memperingati atau memeriahkan momen-momen penting.

Pertunjukan adu domba menampilkan pertarungan dua ekor domba yang saling beradu. Domba dibuat saling berhadapan, kemudian keduanya ditarik mundur hingga jarak sekitar 15 meter. Setelah dilepaskan, keduanya saling menanduk sehingga membuat pantat kedua domba naik akibat benturan keras. Tubrukan ini terjadi berulang kali hingga salah satu domba menyerah atau sekarat. Domba yang diadukan mendapat perawatan khusus berupa pemberian jamujamuan oleh pawangnya. Jika ada domba yang mogok di tengah pertandingan, sang pawang menyentil atau meremas buah zakar domba dengan keras (Raap, 2013: 165).

Serupa dengan cerita pada dongeng Roesdi djeung Misnem di atas, beberapa fakta memperlihatkan narasi yang sama, yakni dalam sumber yang diproduksi sejak 
akhir abad ke-19. Koran De Locomotief edisi 22 Juni 1896 misalnya memberitakan suatu momen penting, yakni kunjungan Raja Siam ke Jawa, khususnya ke Bandung dan Garut. Ketibaan rombongan Kerajaan Siam tersebut disambut secara khusus oleh residen Priangan, sekaligus disuguhi pertunjukan-pertunjukan menghibur, seperti balap kuda dan adu domba. Dengan menaiki kereta api dari Batavia, Raja Siam beserta rombongannya tiba di Bandung dan menginap di Hotel Homman. Lalu, mereka bertamasya ke Garut, dengan mengunjungi Talaga Bodas dan Kawah Papandayan. Mereka menginap di suatu pesanggrahan di Cisurupan (De Locomotief, 22 Juni 1896).

Pertunjukan adu domba juga dilakukan untuk memperingati momen penting lainnya, yakni pengangkatan Ratu Wilhelmina sebagai Ratu Belanda pada 31 Agustus 1898. Gaung perayaan tersebut sampai hingga ke Garut, yaitu ketika perayaan tersebut diselenggarakan pada 7 September 1898. Acara diawali dengan menyanyikan lagu kebangsaan Belanda pada pukul 9 pagi oleh anak-anak Eropa di sekolah Eropa dan oleh anak-anak pribumi di sekolah pribumi, disertai pemberian lencana dan hadiah. Acara dilanjutkan dengan permainan rakyat di alun-alun. Pada sore hari pukul 16.30 diselenggarakan prosesi oleh kepala pribumi disertai pertunjukan adu domba. Setelah itu, pada pukul 17.30 diadakan pesta untuk anak-anak di lingkungan Eropa dan Pribumi. Pada pukul 20.30, parade Tionghoa dan pesta kembang api diselenggarakan di alun-alun. Acara terakhir dilakukan pada pukul 21.30, yakni pesta di lingkungan Eropa untuk orang Eropa, dan pesta di lingkungan Pribumi untuk kepala pribumi (De Preanger-Bode, 31 Agustus 1898).

Berbagai permainan rakyat ditampilkan di alun-alun Garut, termasuk pertunjukan adu domba (De PreangerBode, 31 Agustus 1898). Selain itu, perayaan tahun baru Jawa atau tahun baru Hijriah juga menampilkan berbagai kemeriahan, seperti yang diberitakan De Locomotief 18 Juli 1902:

"De javaansche Nieuwjaarsdag werd geboren in zonneglans en jong en oud, uitgedost in de kleurigste baadjes (iets speciaal vroolijks van de PreangerRegentschappen) spoedde zich naar de aloon-allon om van de volksspelen te geniten. De grootste attractie waren de rammengevechten, die zouden plaats hebben; we hadden al reusachtige pracht-exemplaren ien voorbijbrengen, die straks hun hersenpannen tegen elkander zouden moeten beproeven".

"Hari tahun baru Jawa (Hijriah) di bawah sinar matahari, tua dan muda mengenakan baju warna-warni (kemeriahan khusus di Keresidenan Priangan) bergegas ke alunalun untuk menikmati permainan rakyat. Daya tarik utama adalah adu domba jantan yang akan berlangsung. Kami telah melihat spesimen besar lewat, yang akan segera menguji kepala mereka satu sama lain".

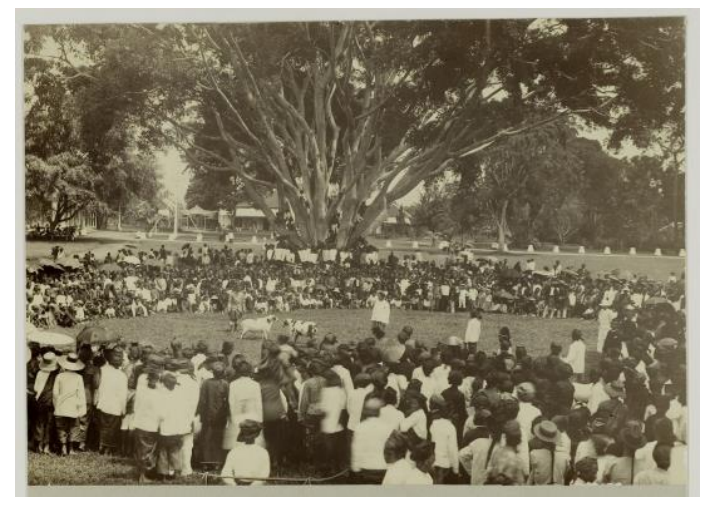

Gambar 1. Adu Domba di Alun-Alun Garut (antara 1901 - 1902)

Sumber: Digital Collections Leiden University Libraries, KITLV 19180. 
Pada 31 Agustus 1904, Koninginnedag atau Hari Ratu juga diperingati di Garut. Setelah melakukan pengibaran bendera pada pagi hari, permainan populer dimainkan di alun-alun, diantaranya adu domba jantan yang dianggap sebagai permainan paling menarik. Pada malam sebelum perayaan, dilakukan pemberian bintang emas kepada Patih Limbangan R. Aria Soeria Katadiredja, penyematan gelar rangga kepada R. Danoekoesoemo, serta sebuah penghargaan diberikan pula kepada Lurah Cianjur. (De Preanger-Bode, 1 September 1904).

Adu domba sangat sering diselenggarakan di alun-alun Garut, di mana bupati Garut memiliki kesenangan yang besar terhadap pertunjukan ini. Setiap minggu pagi ketika tidak disibukkan dengan tugas resmi, bupati seringkali melihat adu domba dan pacuan kuda dari atas babancong. Babancong adalah sebuah bangunan berbentuk kubah yang berada di depan kediaman bupati sebagai sarana bupati menyapa rakyatnya (Van Dyck, 1922: 64). Adu domba juga selalu menjadi hiburan pada saat perayaan Lebaran di Garut, seperti yang diberitakan koran Bataviaasch Nieuwsblad terbitan 29 September 1888.

Animo masyarakat yang tinggi membuat adu domba selalu hadir dalam acara-acara besar yang dilakukan di wilayah Priangan. Pun dengan Pekan Raya (jaarmarkt) yang diselenggarakan di Bandung pada 30 Maret hingga 1 April 1907. Beberapa pertunjukan binatang mewarnai pameran tersebut, mulai dari pacuan kuda, dancing horse, hingga adu domba jantan (De Preanger-Bode, 15 Maret 1907). Di distrik Ujungberung Wetan, perayaan dalam rangka pemberian gelar rangga kepada Wedana Ujungberung Wetan, disertai khitanan cucunya, digelar berbagai acara, seperti adu domba dan nayuban (De Preanger-Bode, 1 Desember 1913).

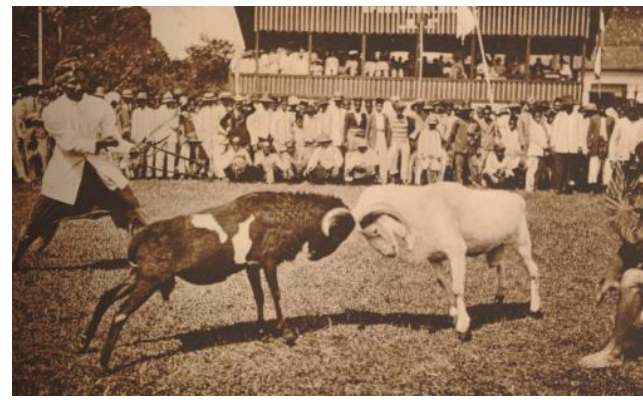

Gambar 2. Adu Domba di Bandung sekitar 1915

Sumber: Digital Collections Leiden University Libraries, KITLV 94249.

Pagelaran adu domba dilakukan juga dalam rangka pergantian nama Desa Cimareme pada 20 November 1922. Desa Cimareme merupakan salah satu desa di Kabupaten Garut yang pernah menjadi tempat terjadinya konflik berdarah pada 1919. Konflik tersebut melibatkan Haji Hassan dan keluarganya yang meninggal akibat rentetan tembakan marsose karena dianggap melakukan "pemberontakan". Perubahan nama ini dilatarbelakangi adanya anggapan citra buruk mengenai nama Cimareme karena peristiwa tersebut. Desa Cimareme pun diganti dengan nama Desa Sukasari pada 20 November 1922. Acara perubahan nama tersebut dilakukan dengan meriah, dengan dihadiri asisten residen, bupati, patih, dan para pejabat pribumi. Dilakukan pula beberapa acara, seperti pawai berhias boneka dan badut, pawai sepeda, serta acara yang paling populer, yaitu adu domba. Menjelang malam, pesta kembang api digelar, diteruskan dengan alunan gamelan, wayang, dan nayuban hingga larut malam (De Preanger-Bode, 29 November 1922; De Sumatra Post, 9 Desember 1922).

Pada perkembangannya, pagelaran adu domba juga dilakukan di luar wilayah Garut dan Bandung. Misalnya, pada Juni 1926, adu domba digelar pada acara besar 
di Batavia, yakni Pasar Gambir ${ }^{2}$ (Bataviaasch Nieuwsblad, 25 Juni 1926).

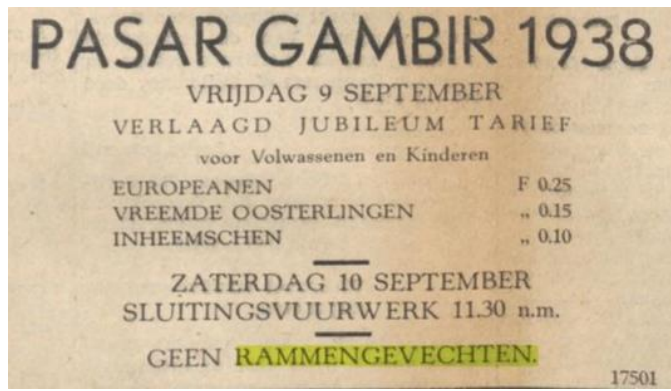

Gambar 3. Iklan pagelaran adu domba pada acara Pasar Gambir 1938

Sumber: Bataviaasch Nieuwsblad, 9 September 1938.

Selain itu, pada 9 Agustus 1928 adu domba diselenggarakan pada pasar malam di Tegal (De Indische Courant, 9 Agustus 1928). Pagelaran serupa juga dilaksanakan di Rangkasbitung pada 5 Juni 1929, yang juga menampilkan adu domba sebagai salah satu bentuk kemeriahannya (Bataviaasch Nieuwsblad, 5 Juni 1929).

Pertunjukan adu domba masih digelar hingga dekade terakhir masa kolonial. Pada September 1938, peringatan 125 Tahun Garut menampilkan adu domba sebagai salah satu acara utamanya, selain pawai, pertandingan gulat, bioskop terbuka (layar tancap), pertandingan sepak bola, dan berbagai pameran (Bataviaasch Nieuwsblad, 1 September 1938). Dua tahun kemudian, di Garut diselenggarakan pula adu domba untuk memeriahkan pembukaan poliklinik di Wanaraja, Garut (Het nieuws van den dag, 2 Januari 1940).

Secara umum, penyelenggaraan adu domba begitu masif dilakukan di wilayah Priangan. Namun demikian, di balik popularitas adu domba, ada kecamankecaman yang mencapnya sebagai permainan yang bersifat kejam.

\footnotetext{
${ }^{2}$ Pasar Gambir merupakan cikal bakal Pekan
} Raya Jakarta yang dimulai sejak 1906

\section{Antara Hiburan dan Penyiksaan Binatang}

Adu domba yang dianggap sebagai hiburan, ternyata menyisakan berbagai kecaman dari orang-orang Eropa. Mempertarungkan dua ekor domba dianggap sebagai permainan yang kejam. Kecaman ini setidaknya telah hadir sejak akhir abad ke-19 yang umumnya disuarakan melalui media massa.

"Drie kwartier lang zagen wij zulke geweldige bonzen, dat ieder onzer onwillekeurig zich over het voorhoofd streek en een gewaarwording van hoofdpijn kreeg, terwijl de rammen geen ander teeken van ontroering gaven dan het uitsteken van de tong en het aflikken van den bek. De eigenaars der dieren, allen wel gekleede menschen, stelden er blijkbaar veel prijs op, dat hun rammen overwinnaars bleven, hoewel er niets anders mede te verdienen was dan eer, en het gevaar bestond, dat de verslagen ram door een bijzonder nijdigen tegenstander geducht met de horens toegetakeld werd".

"Selama tiga seperempat jam, kami melihat sepasang domba jantan baru, saling berhadapan, dan mendengar mereka bertubrukan dengan sangat keras sehingga masing-masing dari kami tanpa sadar mengusap dahi dan merasakan sakit kepala, sementara domba jantan itu menyerah. Tidak ada tanda emosi lain selain menjulurkan lidah dan menjilati mulut. Para pemilik domba yang semuanya berpakaian bagus, menaruh harga tinggi bahwa domba jantannya terus menjadi penakluk, meskipun tidak ada yang bisa diperoleh dari hal itu 
selain kehormatan, dan berani mengambil resiko bahwa domba jantan kalah dilukai oleh kebuasan tanduk lawan yang ditakuti" (Bataviaasch Nieuwsblad, 29 September 1888). ${ }^{3}$

Dari koran tersebut terlihat bahwa ketidaksukaan orang Eropa terhadap adu domba sudah hadir sejak akhir abad ke-19, masa di mana adu domba mulai populer dilakukan di Priangan. Kritik terhadap pertunjukan adu domba juga disuarakan dalam cerita bersambung berjudul "Zaterdagavondcadetjes" yang ditulis oleh Kees Moppering, yang dimuat pada koran de Preanger Bode. Pada edisi 27 Agustus 1900, Kees Moppering menceritakan ketidaksukaannya pada adu domba yang cukup banyak digemari oleh penduduk Sunda. Menurutnya, pertunjukan tersebut tidak baik apalagi tidak ada larangan dari polisi. Ia menambahkan:

"[...] daarbij blijft ' $n$ ram toch altijd maar doodgoed schaap; $d^{\prime} r$ zit geen fut in; je moet ze eerst woedend maken voor ze elkander aanvallen en voor ze op het commando van 'n 12jarigen snotjongen elkaar met de stalen hoorns den kop te pletter stooten. De politie heeft groot gelijk, dat ze zich met de bescherming van dit sullige schepsel niet ophoudt... de rammen kunnen voor mijn part allemaal ' $n$ hersenschudding krijgen $[\ldots]$ ".

"[...] seekor domba jantan selalu merupakan domba yang amat baik, tidak ada tenaga di dalamnya, Anda harus

\footnotetext{
${ }^{3}$ Penggalan kalimat di atas dimuat dalam koran Bataviaasch Nieuwsblad edisi 29 September 1888 dengan judul "Lebaran te Garoet". Judul ini dimuat kembali dalam buku yang ditulis $\mathrm{M}$. Buys berjudul In het hart der Preanger dan diterbitan pada 1900.
}

\begin{abstract}
membuat mereka marah sebelum mereka menyerang satu sama lain dan sebelum mereka saling menghancurkan dengan tanduk baja atas perintah anak berusia 12 tahun. Polisi sangat tepat bahwa mereka tidak perlu repot untuk melindungi makhluk lemah ini ... Para domba jantan yang saya pedulikan bisa mengalami geger otak [...]" (De PreangerBode, 27 Agustus 1900).
\end{abstract}

Kees Moppering melihat bahwa adu domba tidak hanya dilakukan oleh orang dewasa dalam pertunjukan "resmi". Adu domba nyatanya menjadi kebiasaan yang sering dilakukan anak-anak saat mereka menggembala dombanya. Dalam Bahasa Sunda dikenal istilah ngadoe atau ngadoekeun, yang berarti membuat dua ekor domba jantan bertarung satu sama lain. Kebiasaan ngadoe pada dasarnya sudah ada pada anak laki-laki Sunda. Mereka suka melatih domba untuk menyeruduk. Seorang anak laki-laki biasanya naik di atas kepala domba dan dengan kesulitan memegang leher domba tersebut untuk mendesaknya menyerang lawan. Mereka pun berusaha untuk mendorong bagian bokong dombanya, lalu menarik ekornya untuk membuatnya beradu. Hal lain yang dilakukan adalah menusuk domba mereka dengan cara yang kejam. Upaya ini berhasil membuat kedua domba berlari dan saling beradu, hingga membuat anak-anak tersebut riang dan bertepuk tangan (De Preanger-Bode, 17 Februari 1898).

Meskipun masih banyak digemari oleh masyarakat pribumi, pertunjukan adu domba sempat dilarang dipertontonkan pada beberapa momen penting di Bandung pada 1908 , seperti peringatan ulang tahun ke-50 Ratu Juliana dan Hari Ratu (koninginnedag) pada 31 Desember. Polisi dan pemerintah telah meminta agar adu domba - yang dilaksanakan di Lapangan Tegallega - dihilangkan dari daftar kedua 
acara tersebut. Pelarangan tersebut didasarkan atas pandangan bahwa adu domba merupakan suatu hal yang "barbar", di mana dua ekor domba dipaksa bertarung beberapa kali dan tidak jarang tanduknya dipotong - meski semuanya begitu menyenangkan untuk beberapa penonton (Het nieuws van den dag, 20 Agustus 1908; Bataviaasch Nieuwsblad, 2 September 1908).

Pada dasarnya, orang Eropa begitu sensitif melihat kekerasan terhadap binatang. Kampanye untuk melarang kekerasan terhadap binatang telah dilakukan di Eropa sejak awal abad ke-19, dan terlihat masif pada akhir abad ke-19. Khusus di Inggris, berbagai pelarangan adu satwa (animal baiting) diberlakukan, seperti adu ayam, adu beruang atau banteng dengan beberapa anjing (bullbaiting atau bear-baiting), serta adu ayam. Regulasi yang tegas ditetapkan pada 1835 melalui Cruelty to Animals Act 1835 (Undang-Undang Kekerasan Binatang 1835), di mana pelaksanaannya tidak lepas dari upaya Society for Prevention of Cruelty to Animals (SPCA) yang dibentuk pada 1824 (Gustaman, 2015: 113-115).

Di Hindia Belanda, kekerasan terhadap binatang diatur dalam pasal 302 ayat 1 dan 2 Wetboek van Strafrecht voor Nederlandsch-Indie (Kitab UndangUndang Hukum Pidana Hindia Belanda) ${ }^{4}$, yang mulai diberlakukan sejak 1 Januari 1918. Sejatinya, adu domba juga masuk ke dalam ketentuan pidana tersebut. Namun, pro dan kontra kemudian muncul seiring masih dilaksanakannya adu domba di wilayah Priangan, seperti yang masih dilakukan hampir setiap pekan di Bale Desa Rancabango, Kecamatan Tarogong,

\footnotetext{
4 Pasal 302 ayat: (1) Perbuatan menganiaya binatang dihukum dengan hukuman penjara selama 4 bulan dan dua minggu atau dengan denda sebanyak 120 gulden; (2) Jika kejahatan itu dilakukan di tempat umum, maka dijatuhkan hukuman penjara selama 6 bulan atau denda sebanyak 120 gulden (Wetboek van Strafrecht voor Nederlandsch-Indie, 1921: 167)
}

Kabupaten Garut (Kaoem Moeda, 25/29 April 1921). Para penyayang binatang menilai bahwa balapan kuda - sebagai pertunjukan yang juga banyak digemari juga harus dihapuskan jika adu domba tidak dilarang (Kaoem Moeda, 18/23 Juli 1921).

Orang-orang Eropa pada dasarnya tidak terlalu meminati pagelaran adu domba. Di Tasikmalaya misalnya, acara adu domba pada Pasar Malam yang diselenggarakan pada Agustus 1922 sangat sedikit menarik penonton dari kalangan orang Eropa (De Preanger-Bode, 5 Agustus 1922).

Beberapa sindiran dialamatkan kepada bupati, khususnya Bupati Garut yang tidak melarang adu domba dengan alasan sebagai bentuk promosi peternakan domba Garut (De Preanger-Bode, 17 Januari 1923). Terlebih, Bupati Garut beserta masyarakatnya sangat menggemari adu domba. Salah satu sindiran di media massa mengatakan bahwa seseorang harus bertanya kepada direktur Veeartsenijschool (Sekolah Kedokteran Hewan), 'apakah adu domba diperlukan sebagai promosi peternakan yang baik?' (Matahari, 30 September 1922). Adu domba sebagai bentuk promosi untuk pembudidayaan domba dirasa tidak relevan dibandingkan dengan promosi yang seharusnya dilakukan dalam bentuk pameran. Pada dasarnya, adu domba sangat menentukan nilai seekor domba diukur dari kondisi saat pertarungan. Jika seekor domba kalah, maka nilainya akan turun. Sebaliknya, seekor domba pemenang akan dihargai dengan harga tinggi oleh sesama orang Sunda, tetapi tidak oleh orang Eropa ( $D e$ Preanger-Bode, 17 Januari 1923).

Pro dan kontra juga mengarah pada daya tahan domba saat pertarungan, khususnya pada dahi domba yang menjadi pusat benturan. Ada anggapan yang menyebutkan bahwa dahi domba tahan terhadap benturan karena memiliki struktur kepala yang kuat. Selain itu, para pemilik domba selalu menggunakan perawatan 
khusus agar otot-otot dahi domba menjadi mati rasa (Gustaman, 2015: 188).

Bupati Bandung pun menjadi sasaran kritik karena di wilayahnya diselenggarakan adu domba yang diikuti oleh 300 ekor domba yang telah dikumpulkan dari seluruh Kabupaten Bandung. Domba yang terpilih dianggap yang paling unggul sehingga membuat para penonton bersorak. Para penyayang binatang menyayangkan hal tersebut yang tidak sesuai dengan slogan-slogan yang terpampang di tempat umum, khususnya sekolah-sekolah (Matahari, 14, 24, dan 30 Januari 1923).

"Behandel de dieren met zachtheid! Spaar de vogels! [Perlakukan binatang dengan lembut! Selamatkan burungburung!]. Slogan-slogan itu tergantung di depan sekolah untuk mengajarkan anakanak agar tidak menyakiti binatang, tetapi di sisi lain, para pembesar membiarkan binatang berkelahi. Kusir Sado didenda karena menggunakan kuda yang terluka, dan orang lain dihukum karena sabung ayam, tetapi di tengah lapangan terbuka domba jantan diizinkan untuk bertarung" (Matahari, 14, 24, dan 30 Januari 1923).

Atas penyelenggaraan adu domba tersebut, Bupati Bandung menyampaikan pernyataan bahwa ia pada dasarnya adalah penentang pertunjukan adu domba, terutama jika melibatkan adanya uang taruhan. Ia pun berjanji untuk mengatur semuanya menjadi lebih baik (Matahari, 14, 24, dan 30 Januari 1923).

Adu domba yang dianggap kejam juga menjadi perhatian Perkumpulan Penyayang Binatang (Vereeniging tot Bercherming van Dieren) cabang Bandung. Hal ini disampaikan pada rapat yang diselenggarakan pada Januari 1930 di Gedung Societiet Concordia (sekarang Gedung Merdeka) (De Preanger-Bode, 30 Januari 1923).

Adanya beberapa kecaman terhadap adu domba, nyatanya tidak membuat adu domba dilarang secara tegas. Beberapa pagelaran masih terus dilakukan di beberapa tempat di Priangan. Salah satu alasan yang membuat adu domba masih sering dilaksanakan adalah pemasukan yang besar sebagai dampak dari banyaknya peminat atau penonton pada setiap penyelenggaraannya. Hal ini salah satunya ditunjukkan pada suatu volksfeesten (pesta rakyat) yang diselenggarakan oleh Wedana Bandung pada minggu pagi 7 Januari 1923. Acara tersebut menampilkan adu domba di alun-alun Bandung, yang diikuti sebanyak 250 domba jantan. Uang dari hasil pertunjukan tersebut akan dialokasikan untuk pembangunan desa atau kampung. Pagelaran tersebut disaksikan oleh banyak masyarakat pribumi, dan juga kepala komisaris polisi, serta dokter hewan (De Preanger-Bode, 8 Januari 1923).

Acara tersebut diprotes oleh beberapa pihak. Salah satu protes dimuat dalam koran De Sumatra Post edisi 29 Januari 1923.

"Zeker, de wedana zal als Soendanees wel weten, wat den Soendanees vermaakt, maar om zijn toevlucht te nemen tot dergelijke, wreede en elke beschaving tergende vermakelijkheden, teneinde aan geld te komen voor de kosten van een nieuwe brug, dus voor het algemeen belang, protersteeren wij hier ten sterkste. Waarom niet eens weer een wedstrijd gehouden in pijl en boog schieten, ook tegen entree. Wij kunnen verzekeren, dat er ook veel geld in het laadje zal komen, vooral wanneer de menak er zich voor spant. Het houden van dergelijk wedstijden bij feestelijke gelegenheden of ten behoeve van het algemeen belang, zal nergens tegenstand vinden..."

"Tentu, sebagai orang Sunda, wedana tahu apa yang bisa menghibur orang Sunda, tetapi tidak dengan menyelenggarakan hiburan 
yang begitu kejam untuk mendapatkan uang untuk biaya pembangunan jembatan baru. Untuk kebaikan bersama, kami melakukan protes keras di sini. Mengapa tidak menyelenggarakan pertandingan panahan dengan biaya masuk. Kami dapat meyakinkan Anda bahwa banyak uang yang akan masuk juga, terutama ketika para menak berusaha. Penyelenggaraan pertandingan semacam itu pada acara-acara pesta untuk kepentingan umum, tidak akan mendapat pertentangan" (De Sumatra Post, 29 Januari 1923).

Koran Bataviaasch Nieuwsblad terbitan 27 Juli 1923 mengulas lagi perihal acara tersebut dalam lingkup perdebatan di dalam lingkup pemerintahan. Pada salah satu laporan disampaikan adanya pengumpulan uang sebesar 800 gulden hasil dari pagelaran adu domba, di mana uang tersebut akan digunakan untuk biaya pembuatan jembatan di kampungkampung. Ada sebuah mosi yang disampaikan oleh seorang Eropa bernama Tuan Schneider pada dewan kota.

"Met rammengevechten kom je voor desa-bruggen al en heel eind, maar als er iets noodig is van steviger constructie, een permanente brug dus, dan is er ielts noodig dat meer publiek trekt en dus meer opbrengt."

"Dengan adu domba, Anda bisa melakukan banyak hal untuk jembatan, tetapi jika sesuatu dibutuhkan untuk konstruksi yang lebih kuat yakni jembatan permanen, maka perlu menarik lebih banyak penonton dan dengan demikian menghasilkan [uang] lebih banyak..." (Bataviaasch Nieuwsblad, 27 Juli 1923).
Tuan Schneider terkesan "menyindir" pemerintah Kota Bandung yang sebelumnya memiliki keinginan untuk menerangi atau membangun kampung-kampung. Tuan Schneider beralasan bahwa pemerintah lamban dalam menangani masalah tersebut, serta terkesan bahwa walikota Bandung tidak tertarik dengan kampung-kampung seperti yang diutarakan beberapa orang pribumi (Bataviaasch Nieuwsblad, 27 Juli 1923).

Pada dasarnya, pagelaran adu domba menjadi suatu paradoks bagi pemerintah kolonial. Hingga berakhirnya masa kolonial, pagelaran adu domba tidak pernah benar-benar dilarang meski telah diberlakukan regulasi perihal kekerasan terhadap binatang. Setelah Indonesia merdeka, pagelaran adu domba tetap menjadi pertunjukan yang diminati di wilayah Priangan, bahkan hingga kini.

\section{PENUTUP}

Popularitas adu domba yang bertahan hingga sekarang bisa dibilang berawal dari "ketidaksengajaan". Impor domba yang dilakukan pada 1860-an oleh K.F. Holle awalnya ditujukan untuk budidaya wol seperti di Eropa. Namun demikian, kawin silang domba impor dan domba lokal menghasilkan jenis domba yang besar dan dianggap gagah untuk beradu. Meski belum bisa dibuktikan secara faktual, masyarakat Sunda memiliki kebiasaan mengadu domba - entah sebelum atau setelah adanya budidaya domba impor.

Secara kuantitas dan kualitas, popularitas adu domba sangat besar sejak akhir abad ke-19, bahkan lebih populer sejak awal abad ke-20. Berbagai event besar di wilayah Priangan selalu mempertontonkan adu domba sebagai pagelaran yang banyak menarik penonton.

Kontroversi pun mengiringi popularitas adu domba, di mana orangorang Eropa penyayang binatang menganggap adu domba sebagai bentuk kekerasan terhadap binatang. Pada dasarnya, hal ini merupakan masalah perspektif. Perspektif Barat perihal 
binatang mengarah pada perlakuan yang "manusiawi" terhadap binatang, seperti yang masif dikampanyekan dan dipraktikkan di Eropa. Perbedaan perspektif ini mengantarkan pada penyebutan adu domba sebagai permainan yang "barbar". Meski muncul berbagai kecaman, terutama disuarakan di media massa, - serta diperkuat dengan adanya regulasi perihal kekerasan terhadap binatang - adu domba tidak dilarang secara tegas pada masa kolonial. Adanya anggapan sebagai bentuk budidaya peternakan, dan juga sebagai penghasil pundi-pundi uang yang besar, membuat adu domba tetap digelar hingga berakhirnya masa kolonial.

\section{DAFTAR SUMBER}

Veeteelt overdruk uit Mededeelingen der Regeering Omtrent (1926).

Advertentie. Bataviaasch Nieuwsblad, 9 September 1938.

Barwegen, M. (2005). Gouden Hoorns; De geschiedenis van de veehouderij op Java, 1850-2000. Proefschrift Landbouwuniversiteit Wagenigen.

Binnenland. Tegal. De Indische Courant, 9 Agustus 1928.

Bokkengevechten. Kaoem Moeda, 25/29 April 1921. Overzicht van de Inlandshe en Maleisch-Chineesche Pers No.18/1921.

Bokkengevechten en Wedrennen. Kaoem Moeda, 18/23 Juli 1921. Overzicht van de Inlandshe en Maleisch-Chineesche Pers No. 30a/1921.

Buys, M. 1900. In Het Hart der Preanger. Leiden: S.C. van Doesburgh.

Crawfurd, J. (1820). History of The Indian Archipelago. Edinburgh: Archibald Constable and Co.

De Aanstaande Pasar Gambir. Bataviaasch Nieuwsblad, 25 Juni 1926.

Deenik, A.C. dan Rd. Djajadiredja. (1913). Roesdi djeung Misnem; Bokoe batjaan pikeun moerid2 di Sakola Soenda. 's-
Gravenhage: Blankwaardt \&

Schoonhoven

De Omdooping der Desa Tjimareme. De

Preanger-Bode, 29 November 1922.

De Omdooping der Desa Tjimareme. De Sumatra Post, 9 Desember 1922.

De Koning van Siam te Garoet. De Locomotief, 22 Juni 1896.

Digital Collections Leiden University Libraries. Rammengevecht op de aloenaloen te Garoet voor het huis van de assitent-resident, diakses pada tanggal 5 April 2021, dari https://digitalcollections.universiteitleiden $. n 1 /$

Dieren-Bescherming. De Preanger-Bode, 30 Januari 1923.

Digital Collections Leiden University Libraries. Rammengevecht te Bandoeng, diakses pada tanggal 5 April 2021, dari https://digitalcollections.universiteitleiden .nl/

Enkele Onderwerpen van Algemeen Belang. Weltevreden: Landsdrukkerij.

Feesten te Bandoeng. Bataviaasch Nieuwsblad, 2 September 1908.

Garoet Bestaat 125 jaar. Bataviaasch Nieuwsblad, 1 September 1938.

Gustaman, B. (2015). Animal Welfare di Hindia Belanda; Perkembangan Wacana Tentang Kesejahteraan Satwa 1896-1942. Tesis Fakultas Ilmu Budaya Universitas Gadjah Mada.

Holle, K.F. (1868). "Merinos-Schapen". Tijdschrift voor Nijverheid en Landbouw in Nederlandsch Indie uitgegeven door de Nederlandsch-Indische Maatschappij van Nijverheid en Landbouw Deel XIII. Batavia: Ogilvie \& Co.

Jaarmarkt. De Preanger-Bode, 15 Maret 1907.

Lebaran te Garoet. Bataviaasch Nieuwsblad, 29 September 1888.

Lubis, N. H. (1998). Kehidupan Kaum Menak Priangan 1800-1942. Bandung: Pusat Informasi Kebudayaan Sunda. 
Mut. Een vacantiereisje op Java. De Locomotief, 18 Juli 1902.

Nederlandsch-Indie Bandoeng, 17 Februari 1989. De Preanger-Bode, 17 Februari 1898.

Nederlandsch-Indie Bandoeng, 31 Agustus 1898. De Preanger-Bode, 31 Agustus 1898.

Pasar Malem te Rangkas. Bataviaasch Nieuwsblad, 5 Juni 1929.

Preanger Kroniek - Raadsoverzicht. Bataviaasch Nieuwsblad, 27 Juli 1923.

Raap, O. J. 2013. Soeka-Doeka Djawa Tempo Doeloe. Jakarta: KPG.

Raffles, T. S. (1830). The History of Java Vol. I. London: John Murray.

Rammengevechten. De Preanger-Bode, 17 Januari 1923.

Rammengevechten. De Sumatra Post, 29 Januari 1923.

Rammengevechten. Matahari, 14, 24, 30 Januari 1923. Overzicht van de Inlandshe en Maleisch-Chineesche Pers No. 6/1923.

Stroomberg, J. (2018). Hindia Belanda 1930. Yogyakarta: IRCiSoD.

Uit Bandoeng. Het nieuws van den dag, 20 Agustus 1908.

Uit Tasikmalaja. De Preanger-Bode, 5 Agustus 1922.

Van die ren daar - uit Garoet schrijft men ons. De Preanger-Bode, 1 September 1904.

Van die ren daar - uit Oedjoengbroeng. De Preanger-Bode, 1 Desember 1913.

Van Dyck, J.Z. (1922). Garoet en Omstreken. Batavia: G. Kolff \& Co.

Volksfeesten. De Preanger-Bode, 8 Januari 1923.

Vooruitgang?. Matahari. 4/30 September 1922. Overzicht van de Inlandshe en MaleischChineesche Pers No. 41/1922.

Wanaradja's Polikliniek - Feestelijke Openning. Het nieuws van den dag voor Nederlandsch-Indie, 2 Januari 1940.
Wetboek van Strafrecht voor NederlandschIndie (1921).

Zaterdagavondcadetjes. De Preanger-Bode, 27 Agustus 1900. 
Patanjala, ISSN 2085-9937 (print), ISSN: 2598-1242 (online) 